\title{
EVALUASI AKTIVITAS ANTIMIKROBA (STREPTOCOCCUS AGALACTIAE) MENGGUNAKAN EXSTRAK BUAH MAHKOTA BUAH (PHALERIA MACROCARPA L.) DENGAN PELARUT YANG BERBEDA
}

\author{
The Evaluation of Antibacterial Activity (Streptococcus agalactiae) by Using \\ Mahkota Dewa Extract (Phaleria macrocarpa L.) with Diffirent Solvent
}

\author{
Lutfiana Safitri ${ }^{1}$, Tri Eko Susilorini ${ }^{2}$, Puguh Surjowardojo ${ }^{3}$
}

1) Student of Animal Husbandry, Brawijaya University, Veteran Street Malang 65145, Indonesia

2) Lecture of Animal Husbandry, Brawijaya University, Malang, Veteran Street Malang 65145, Indonesia

3) Lecture of Animal Husbandry, Brawijaya University, Malang, Veteran Street Malang 65145, Indonesia E-mail:lutfianasafitri13@gmail.com

Diterima 23 Mei 2017, diterima pasca revisi 10 Juli 2017 Layak terbit 11 Juli 2017

\begin{abstract}
This research was aimed to determine the antibacterial activity of mahkota dewa extract and the effective concentration of mahkota dewa extract against Streptococcus agalactiae. The material ware Streptococcus agalactiae bacteria which isolated from mastitis milk, mahkota dewa which extracted using Aquades and ethanol. The method design was experiment research using Nested Design with 6 treatments and 5 replications. The concentrations of the treatments were P1 (10\%), P2 (20\%), P3 (30\%), P4 (40\%) and P5 (50\%) and positive control $P 0$ (iodips 10\%). The collected data were analyzed using the analysis of variance indicated the significant effects, the least significant different test (LSD) was then employed. Mahkota dewa extract using ethanol (50\%) result showed that significantly $(P<0.01)$ on growth of Streptococcus agalactiae was $20.34 \pm 0.9 \mathrm{~mm}$. Mahkota dewa extract using aquades $(50 \%)$ result showed that significantly $(P<0.01)$ on growth of Streptococcus agalactiae was $10.0 \pm 0.50 \mathrm{~mm}$. The conclusion of this research is Mahkota dewa fruits extract with ethanol had inhibitory higher in habiting the Streptococcus agalactiae bacteria compared to aquades solvent. The best of treatment of Mahkota dewa fruits extract with ethanol and Aquades solvent in concentration 50\% had a high ability to inhibit the growth of Streptococcus agalactiae.
\end{abstract}

Key words : Phaleria macrocarpa L., Ethanol, and Antibacterial

\section{PENDAHULUAN}

Mahkota dewa merupakan salah satu tumbuhan herbal yang berkhasiat untuk menyembuhkan penyakit ringan seperti alergi, pusing hingga penyakit berat seperti kanker. Daging buah mahkota dewa mengandung senyawa flavonoid, alkaloid dan turunan fenil propanoid. Senyawasenyawa tersebut, memiliki fungsi optimal sebagai antibakteri. Flavonoid memiliki efek anti-tumor, triterpenoid dan steroid saponin mempunyai efek anti inflamasi, analgesik dan sitotoksik. Senyawa fenol ataupun polifenol mempunyai efek antikanker. Senyawa tanin mempunyai efek antikanker dan memiliki antivirus. Hudaya
(2015) mengungkapkan buah mahkota dewa kering memiliki kandungan fenolik sebagai anti mikroba lebih besar $60,5 \mathrm{mg}$ ekuivalen asam galat dibandingkan buah blackberry yang hanya mengandung $12 \mathrm{mg}$ ekuivalen asam galat, dan blueberry yang mengandung $42 \mathrm{mg}$ ekuivalen asam galat.

Kasus bakteri yang menimbulkan kesulitan bagi peternak adalah mastitis subklinis. Penyebab masititis subklinis yang sering terdeteksi adalah Staphylococcus aureus, Streptococcus agalactiae, Staphylococcus epidermidis, dan Escherichia coli. Sholikatin (2014) patogen yang sering ditemukan dalam kasus mastitis subklinis yaitu Streptococcus agalactiae berkisar 92\% - 60,6\% dan Staphylococcus 
aureus berkisar $67 \%$ - 18,1\%. Pada penelitian sebelumnya yang telah dilakukan oleh Nikham (2012) simplisia pada buah mahkota dewa yang diradiasi pada dosis 10 kGy, memiliki kemampuan menghambat pertumbuhan S. aureu dengan kosentrasi minimum $5 \%$.

Pengolahan dalam bentuk ekstrak memiliki keuntungan dari segi keefektifan zona hambat, pada buah mahkota dewa memiliki efek antibakteri lebih besar 4 kali dibandingkan dengan bagian daunnya (Widyastutik, 2006). Ekstraksi merupakan metode isolasi suatu senyawa dari bahan alam dengan menambahkan suatu pelarut yang tepat. Metode ekstraksi yang digunakan dalam penelitian ini yaitu metode maserasi, dimana lebih praktis, tidak memerlukan panas sehingga lebih tergantung dengan lama waktu maserasi dan kepolaran pelarut. Pelarut yang digunakan yaitu pelarut aquades dan pelarut ethanol. Pelarut aquades memiliki keuntungan mudah didapatkan, pelarut etanol merupakan pelarut yang mampu melarutkan senyawa yang bersifat polar dan nonpolar (Sibuea, 2015). Pemilihan kedua pelarut karena kandungan senyawa kimia pada Mahkota dewa ada yang bersifat larut dalam ethanol dan aquades, dan ada yang berupa senyawa yang tidak larut dalam pelarut nonpolar.

Meninjau penelitian tersebut, perlu dilakukan pengujian lebih lanjut mengenai efektivitas ekstrak buah mahkota dewa menggunakan pelarut aquades maupun ethanol sebagai antimikrobial pada bakteri mastitis subklinis khususnya Streptococcus agalactiae.

\section{BAHAN DAN METODE}

\begin{abstract}
Alat dan Bahan
Peralatan yang digunakan adalah pisau, timbangan digital, oven, nampan, baskom, gelas ukur $1 \mathrm{~L}$, spatulas, Rotary Evaporator, shaker incubator dan Grinder, botol kultur, inkubator. autoklaf, timbangan analitik, pipet mikro $1 \mathrm{~mL}$, tabung reaksi, cawan petri, oose, spreader, pipet, bola hisap, mikropipet, kertas cakram, lampu spirtus/bunsen, jangka sorong, erlenmeyer, slide glass, dan vortex.

Bahan yang digunakan yaitu iodips $10 \%$, aquades, ethanol $96 \%$, dan simplisia buah mahkota dewa, spirtus, medium Nutrient Broth (NB), Muller Hinton Agar (MHA), reagen uji fitokimia, kertas sampul coklat, karet gelang, plastik PE, masker, aluminium foil, kapas medis, kertas saring whatman dan tissue roll.
\end{abstract}

\section{Materi Penelitian}

1. bakteri Streptococcus agalactiae dengan nilai absorbansi $10^{8} \mathrm{CFU} / \mathrm{mL}$

2. ekstrak daging buah Mahkota Dewa dengan pelarut aquades, dan ethanol $96 \%$,

3. Larutan iodips $10 \%$ sebagai kontrol

\section{Metode Penelitian}

Metode penelitian yang digunakan adalah percobaan dengan 6 perlakuan ekstrak buah mahkota dewa (EBMD) dan 5 ulangan. Metode menggunakan analisis ANOVA dengan Racangan Acak Lengkap (RAL) pola tersarang. Kosentrasi perlakuan dapat dilihat pada Tabel 1.

Tabel 1. Kosentrasi Perlakuan Ekstrak Buah Mahkota Dewa (EBMD)

\begin{tabular}{|c|c|c|}
\hline \multirow{2}{*}{$\begin{array}{c}\text { Nama } \\
\text { Perlakuan }\end{array}$} & \multicolumn{2}{|c|}{ Perlakuan yang diberikan } \\
\hline & Ekstrak pelarut ethanol & Ekstrak pelarut aquades \\
\hline P0 (kontrol) & Iodips $10 \%$ & Iodips $10 \%$ \\
\hline P1(10\%) & $0,5 \mathrm{~mL}$ EBMD $+4,5 \mathrm{~mL}$ aquades & 0,5 mL EBMD + 4,5 mL aquades \\
\hline $\mathrm{P} 2(20 \%)$ & 1 mL EBMD + 4 mL aquades & $1 \mathrm{~mL}$ EBMD + 4 mL aquades \\
\hline P3(30\%) & 1,5 $\mathrm{mL}$ EBMD + 3,5 $\mathrm{mL}$ aquades & 1,5 mL EMD + 3,5 mL aquades \\
\hline $\mathrm{P} 4(40 \%)$ & 2 mL EBMD + 3 mL aquades & 2 mL EMD + 3 mL aquades \\
\hline P5(50\%) & 2,5 mL EMD + 2,5 mL aquades & 2,5 mL EMD + 2,5 $\mathrm{mL}$ aquades \\
\hline
\end{tabular}




\section{Prosedur Penelitian}

\section{Pembuatan EBMD (Ekstrak Buah mahkota Dewa)}

Buah Mahkota Dewa dikupas, dicuci, dan dipotong dadu dengan ukuran $2 \times 2 \mathrm{~cm}$. Buah yang telah dipotong lalu ditimbang hingga diperoleh massa sebanyak $500 \mathrm{~g}$. potongan buah kemudian dioven pada suhu $50^{\circ} \mathrm{C}$ selama 24 jam selanjutnya hasil oven akan digrinder. Simplisia hasil grinder dilakukan maserasi selama 3 hari mengunakan 2 pelarut (akuades, dan ethanol). Kemudian dilakukan evaporasi dengan metode rotary Evaporator. (Nikham. dkk., 2012).

\section{Pembuatan Medium Muller Hinton Agar (MHA)}

Pembuatan medium Muller Hinton Agar (MHA) sebagai berikut : (Zahro, 2013)

1. Media MHA ditimbang sebanyak 12,16gram kemudian dimasukkan ke dalam Erlenmeyer $500 \mathrm{~mL}$, kemudian dilarutkan dengan $320 \mathrm{~mL}$ aquades steril, dipanaskan sampai mendidih.

2. MHA yang telah dibuat ditutup kertas aluminium dan disterilkan dalam autoklaf 15 menit suhu 1210C.

3. Media dituangkan ke dalam cawan petri yang akan digunakan, ditunggu hingga padat. kemudian cawan petri dibungkus dan disimpan dilemari es. Media dapat digunakan langsung pada saat akan inokulasi.

\section{Pengujian daya Hambat}

Proses pengujian daya hambat menggunakan metode kertas cakram sebagai berukut: (Rumondor, 2015)

1. Tuangkan medium MHA yang telah disterilisasi ke dalam 20 cawan petri lalu didiamkan hingga memadat.

2. Diambil 0,1 mL masing-masing kultur bakteri lalu dimasukkan ke permukaan medium MHA yang telah padat, ratakan menggunakan spreader glass.

3. masukkan kertas cakram kedalam ekstrak buah mahkota dewa dengan pinset steril pada masing-masing kosentrasi $(10 \%, 20 \%, 30 \%, 40 \%, 50 \%$ dan perlakuan kontrol dengan iodips dan aquades steril) direndam \pm 1 menit, kemudian dipindahkan dengan pinset steril ke medium MHA yang telah berisi S. agalactiae secara aseptis.
4. diinkubasi pada suhu $37^{\circ} \mathrm{C}$ selama 1x24 jam. Diameter zona hambat yang terbentuk berupa daerah bening disekitar kertas cakram pada masing-masing kosentrasi lalu diukur menggunakan jangka sorong.

\section{Uji fitokimia}

Penentuan kandungan senyawa kimia dilakukan melalui uji fitokimia. uji fitokimia pada buah mahkota dewa dilakukan pada senyawa Flavonoid menggunakan metode Wilstater, uji senyawa Tanin mengunakan metode metode $\mathrm{FeCl} 3$, Saponin menggunakan metode Forth dan Alkaloid menggunakan metode Dragendrof. Senyawa-senyawa tersebut memiliki kemampuan antibakteri yang optimal.

\section{HASIL DAN PEMBAHASAN}

Sampel buah mahkota dewa (Phaleria macrocarpa L.) yang digunakan berupa daging buah yang sudah matang, ditandai dengan warna merah serta memiliki tekstur lebih lunak. Buah mahkota dewa yang sudah matang memiliki kandungan senyawa aktif yang lebih banyak, kemudian buah tersebut dipisahkan dari bijinya yang mengandung racun (Tristyanto, 2011). Simplisia buah mahkota dewa ditampilkan pada Gambar 1.

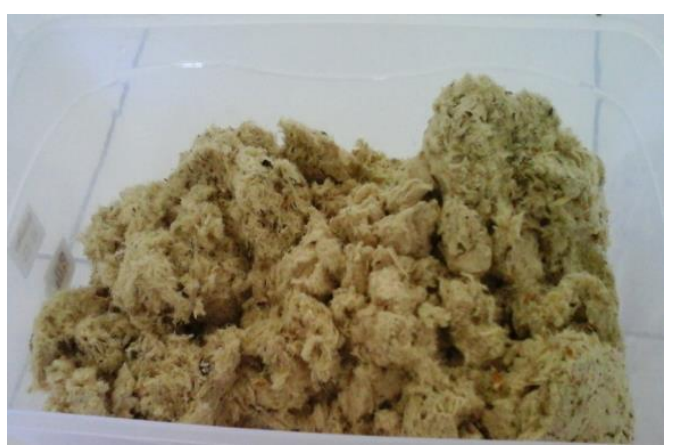

Gambar 1. Simplisia Buah Mahkota Dewa

Bentuk simplisia memudahkan cairan penyari dalam menembus dinding sel dan masuk ke dalam rongga sel yang mengandung zat aktif sehingga zat aktif akan lebih banyak dihasilkan.

Pada penelitian ini, pelarut yang digunakan yaitu pelarut aquades dan ethanol. Hasil perbandingan daya hambat ekstrak buah mahkota dewa menggunakan 
pelarut aquades dan ethanol terhadap bakteri Streptococcus agalactiae dapat dilihat pada Tabel 2.

Tabel 2. Rata-Rata Zona Hambat Ekstrak Buah Mahkota Dewa menggunakan Pelarut Aquades dan Ethanol terhadap Bakteri Streptococcus Agalactiae

\begin{tabular}{cc}
\hline Perlakuan & $\begin{array}{c}\text { diameter zona hambat } \\
\text { EBMD }(\mathrm{mm})\end{array}$ \\
\hline P0 ( iodips 10\% ) & $3,46 \pm 1,50^{\mathrm{a}}$ \\
P1 (EBMD pelarut & $27,40 \pm 0,22^{\mathrm{b}}$ \\
$\begin{array}{c}\text { Aquades) } \\
\text { P2 (EBMD pelarut } \\
\text { Ethanol) }\end{array}$ & $63,92 \pm 0,25^{\mathrm{c}}$ \\
\hline
\end{tabular}

Keterangan : superskrip yang berbeda (a-c) pada kolom yang sama menunjukkan hasil yang berbeda sangat nyata $(\mathrm{p}<$ $0,01)$

Hasil penelitian menunjukkan zona hambat P1 (aquades) dikategorikan kuat dengan nilai hambat $27,40 \mathrm{~mm}$. Hasil tersebut diikuti P12 (ethanol) yang dikategorikan kuat dengan nilai hambat lebih tinggi yaitu $63,92 \mathrm{~mm}$. zona hambat yang terbentuk dari pelarut ethanol lebih tinggi dibandingkan terhadap pelarut aquades disebabkan karena perbedaan sifat polar pada kedua pelarut tersebut, sehingga diameter zona hambat yang timbul sangat berbeda nyata. Lisdawati (2006) menyatakan perbedaan polaritas pada pelarut yang digunakan untuk proses ekstraksi memiliki pengaruh pada kandungan senyawa metabolit sekunder di dalam sampel. Sibuea (2015) mengungkapkan pelarut aquades merupakan jenis pelarut yang mudah didapatkan, bersifat netral, serta memiliki titih didih yang cukup tinggi sehingga memudahkan senyawa kimia pada buah mahkota dewa mengalami kerusakan saat proses evaporasi untuk pengentalan rendemen ekstraksi. Sani (2014) pelarut ethanol termasuk jenis pelarut yang dapat melarutkan senyawa fitokimia lebih maksimal karena masih mengandung air yang membantu proses ekstraksi sehingga senyawa tersebut dapat tertarik dalam ethanol dan dapat tertarik dalam air. Senyawa kimia yang dapat larut dalam pelarut polar seperti asam amino, gula, beberapa senyawa fitokimia seperti alkaloid, flavonoid, glikosida flavonoid serta klorofil selain itu, palarut ethanol juga menghasilkan rendemen yang tinggi dengan ditandai oleh ekstrak yang berwarna hijau pekat.

\section{Hasil Uji Daya Hambat Ekstrak Buah Mahkota Dewa menggunakan Pelarut Ethanol terhadap Bakteri Streptococcus agalactiae \\ Hasil pada penelitian ini} menunjukkan bahwa rata-rata diameter zona hambat oleh ekstrak buah mahkota dewa dengan pelarut ethanol pada konsentrasi P1 (10\%) sampai P5 (50\%) berpengaruh sangat nyata $(\mathrm{P}<0,01)$ terhadap pertumbuhan bakteri Streptococcus agalactiae. Hasil rata-rata pengukuran diameter zona hambat ekstrak buah mahkota dewa menggunakan pelarut ethanol terhadap bakteri Streptococcus agalactiae dapat dilihat pada Tabel 3.

Tabel 3. Hasil rata-rata pengukuran diameter zona hambat ekstrak buah mahkota dewa menggunakan pelarut ethanol terhadap bakteri Streptococcus agalactiae

\begin{tabular}{cc}
\hline Perlakuan & $\begin{array}{l}\text { Diameter Zona } \\
\text { Hambat }(\mathbf{m m})\end{array}$ \\
\hline P0 (iodips 10\%) & $3,46 \pm 1,50^{\mathrm{m}}$ \\
P1 (10\%) & $4,3 \pm 0,91^{\mathrm{n}}$ \\
P2 (20\%) & $9,59 \pm 0,86^{\mathrm{o}}$ \\
P3 (30\%) & $11,15 \pm 0,40^{\mathrm{p}}$ \\
P4 (40\%) & $18,54 \pm 0,93^{\mathrm{q}}$ \\
P5 (50\%) & $20,34 \pm 0,92^{\mathrm{r}}$ \\
\hline
\end{tabular}

Keterangan: superskrip yang berbeda (m-r) pada kolom yang sama menunjukkan hasil yang berbeda sangat nyata $(\mathrm{P}<0,01)$

Hasil zona hambat dari penelitian tersebut yaitu P0 (iodips 10\%), P1 (10\%) dan P2 (20\%) tidak memiliki kekuatan zona hambat dengan nilai zona hambat berturut-turut yaitu $3,49 \mathrm{~mm}, 4,3 \mathrm{~mm}$, 9,59 mm. P3 (30\%) memiliki kekuatan zona hambat lemah dengan nilai zona hambat $11,15 \mathrm{~mm}$. (40\%) memiliki kekuatan zona hambat sedang dimana diameter zona hambat adalah $18,54 \mathrm{~mm}$. P5 (50\%) memiliki kategori zona hambat kuat dengan diameter zona hambat 20,34 mm. Hasil tersebut menunjukkan 
bahwa ekstrak buah mahkota dewa menggunakan pelarut ethanol dengan kosentrasi P5 (50\%) mampu menghambat pertumbuhan bakteri Streptococcus agalactiae lebih tinggi dibandingkan dengan P0 (iodips 10\%), P1 (10\%), P2 (20\%), P3 (30\%) dan P4 (40\%) Greenwood (1995).

Berdasarkan sampel penelitian pada kosentrasi $50 \%$ diperoleh $5 \mathrm{x}$ lebih besar dibandingkan kosentrasi $10 \%$. Hal ini menandakan bahwa aksi antibakteri sebagai bakteriosidal maupun bakteriostatik sangat bergantung pada dosis maupun daya aktif dari kosentrasi yang diberikan. Semakin tinggi kosentrasi, efektifitas penghambatan terhadap bakteri semakin meningkat. Semakin tinggi pengenceran maka $\mathrm{pH}$ ekstrak akan berubah menjadi netral, sehingga semakin sedikit pengenceran daya hambat yang dihasilkan akan semakin tinggi.

\section{Hasil Uji Daya Hambat Ekstrak Buah Mahkota Dewa menggunakan Pelarut Aquades terhadap Bakteri Streptococcus agalactiae}

Hasil penelitian diketahui bahwa ratarata diameter zona hambat oleh ekstrak buah mahkota dewa menggunakan pelarut aquades pada kosentrasi 10\% (P1), 20\% (P2), 30\% (P3), $40 \%$ (P4), dan 50\% (P5) memberikan nilai yang berpengaruh sangat nyata $(\mathrm{P}<0,01)$ terhadap pertumbuhan bakteri Streptococcus agalactiae. Hasil rata-rata pengukuran diameter zona hambat ekstrak buah mahkota dewa menggunakan pelarut aquades terhadap bakteri Streptococcus agalactiae dapat dilihat pada Tabel 3.

Hasil uji daya hambat diketahui bahwa ekstrak buah mahkota dewa menggunakan pelarut aquades dengan kosentrasi $10 \%$ (P1), 20\% (P2), 30\% (P3), 40\% (P4), dan $50 \%$ (P5) tidak memberikan kekuatan daya hambat terhadap bakteri Streptococcus agalactiae. Diameter masing-masing pada kosentrasi iodips 10\% (P0), 10\% (P1), 20\% (P2), 30\% (P3), $40 \%(\mathrm{P} 4)$, dan $50 \%$ (P5) secara berurutan yaitu $3,49 \mathrm{~mm}, 1,552 \mathrm{~mm}$, 2,29 $\mathrm{mm}, 2,91 \mathrm{~mm}$, dan 4,31 mm. Pada kosentrasi $50 \%$ (P5) memiliki nilai hambat lebih tinggi dibandingkan dengan pelarut lainnya, namun tidak ada kekuatan untuk daya hambat bakteri Streptococcus agalactiae.
Tabel 4. Hasil rata-rata pengukuran diameter zona hambat ekstrak buah mahkota dewa menggunakan pelarut aquades terhadap bakteri Streptococcus agalactiae dapat dilihat pada

\begin{tabular}{cc}
\hline Perlakuan & $\begin{array}{c}\text { Diameter Zona } \\
\text { Hambat }(\mathbf{m m})\end{array}$ \\
\hline P1 (10\%) & $1,552 \pm 0,5^{\mathrm{a}}$ \\
P2 (20\%) & $2,29 \pm 0,72^{\mathrm{b}}$ \\
P0 (iodips 10\%) & $3,46 \pm 1,50^{\mathrm{c}}$ \\
P3 (30\%) & $4,31 \pm 1,06^{\mathrm{d}}$ \\
P4 (40\%) & $9,25 \pm 0,93^{\mathrm{e}}$ \\
P5 (50\%) & $10 \pm 0,50^{\mathrm{f}}$ \\
\hline
\end{tabular}

Keterangan : superskrip yang berbeda (a-f) pada kolom yang sama menunjukkan hasil yang berbeda sangat nyata $(\mathrm{P}<0,01)$

Hasil dari penelitian tersebut terbukti bahwa pada kosentrasi P5 (50\%) memiliki kadar ekstrak buah mahkota dewa lebih tinggi dibanding dengan kosentrasi lainnya. Berdasarkan sampel penelitian memberikan kecenderungan, semakin tinggi kosentrasi, efektifitas penghambatan terhadap bakteri semakin meningkat. Roslizawaty (2013) mengungkapkan bahwa seiring meningkatnya kosentrasi zat anti bakteri, maka akan meningkat pula kandungan senyawa serta meningkat pula kemampuan membunuh bakteri menjadi lebih besar.

\section{Hasil Uji Aktivitas Antibakteri Ekstrak Buah Mahkota Dewa}

Berdasarkan hasil pemeriksaan fitokimia, ekstraksi menggunakan pelarut aquades maupun ethanol menunjukkan hasil positif pada uji tanin dengan nilai masing-masing pelarut yaitu (++). Hasil uji tanin menunjukkan hasil positif ditandai dengan adanya perubahan warna menjadi hijau tua mendekati hitam gelap pada kedua ekstrak dengan pelarut ethanol maupun aquades, setelah direaksikan dengan $\mathrm{NaCl}$ $10 \%$ dan 2 tetes $\mathrm{FeCl} 3$. Salasa (2012) mengungkapkan pada senyawa tanin bersifat (bakteriosidal) atau memiliki kemampuan merusak membran sel bakteri, dengan mengkerutkan dinding sel atau membran sel sehingga mengganggu permeabilitas sel itu sendiri. Akibat 
terganggunya permeabilitas, sel tidak dapat melakukan aktivitas hidup, sehingga terjadi koagulasi protoplasma bakteri kemudian pertumbuhannya terhambat bahkan mati. Tanin merupakan senyawa yang mampu membentuk zat besi, sehingga menimbulkan gangguan pada membran sel bakteri. Pada bakteri aerob, zat besi sangat dibutuhkan untuk melakukan berbagai fungsi, seperti pengurangan perkusor ribonukleotida pada DNA, dan pembentukan haem (Zakaria, 2006). Hasil uji fitokimia ditampilkan pada Tabel 5 .

Tabel 5. Hasil uji fitokimia

\begin{tabular}{cccc}
\hline No & $\begin{array}{l}\text { Senyawa } \\
\text { kimia }\end{array}$ & \multicolumn{2}{c}{ Pelarut Ekstraksi } \\
Aquades & Ethanol \\
\hline $\mathbf{1}$ & Tanin & ++ & ++ \\
$\mathbf{2}$ & Flavonoid & - & ++ \\
$\mathbf{3}$ & Alkaloid & ++ & ++ \\
$\mathbf{4}$ & Saponin & ++ & ++ \\
\hline Keterangan : & superskrip & yang berbeda \\
& & diatas & menunjukkan \\
& & hasil $(++)=$ sangat banyak; \\
& & $(+)=$ ada; $(-)=$ tidak ada
\end{tabular}

Senyawa flavonoid dari hasil uji fitokimia pada sampel ekstrak menggunakan pelarut aquades menunjukkan hasil yang negatif (-), sedangkan pada hasil esktrak menggunakan pelarut ethanol menunjukkan hasil positif dengan nilai $(++)$. Hasil uji flavonoid menunjukkan hasil positif ditandai dengan perubahan warna jingga pada ekstrak menggunakan pelarut ethanol, setelah direaksikan methanol panas $50 \%$, ditambahkan serbuk logam $\mathrm{Mg}$ dan $\mathrm{HCl}$ pekat 0,5M. Kristianti (2008) menyatakan kekurangan metode maserasi yaitu membutuhkan waktu perendaman yang lama, serta hasil ekstrak air yang dihasilkan akan mengalami waktu rusak/ hilangnya senyawa kimia yang lebih cepat ditandai dengan hilangnya aromau manis serta timbul bau. Senyawa flavonoid bersifat (bakterostatik) atau memiliki kemampuan antibakteri dengan cara membentuk senyawa kompleks terhadap protein ekstraseluler yang mengganggu integritas membran bakteri, mengganggu proses metabolism, kemudian merusak dinding sel bakteri (Gunawan, 2008). Mekanisme antibakteri dari senyawa flavonoid dapat terjadi akibat reaksi antara senyawa lipid dan asam amino dengan gugus alkohol, sehingga dinding sel mengalami kerusakan dan mengakibatkan senyawa tersebut dapat masuk kedalam inti sel bakteri. Senyawa ini kemudian akan bereaksi dengan DNA pada inti sel bakteri. Akibat perbedaan kepolaran antara lipid dan penyusun DNA dengan gugus alkohol pada senyawa flavonoid akan terjadi reaksi sehingga struktur lipid dari DNA bakteri sebagai inti sel bakteri akan mengalami kerusakan dan lisis. Mahkota dewa yang diekstrak menggunakan pelarut ethanol menampakkan hasil senyawa flavonoid, sehingga memberikan hasil zona hambat lebih tinggi 63,92 $\mathrm{mm}$ dibandingkan pelarut aquades dengan zona hambat $27,40 \mathrm{~mm}$.

Senyawa alkaloid dari uji fitokimia pada kedua sampel ekstrak menggunakan pelarut ethanol maupun pelarut aquades menunjukkan hasil positif dengan nilai $(++)$. Hasil uji alkaloid ditandai dengan timbulnya endapan dan perubahan warna menjadi jingga menuju coklat setelah direaksikan dengan $\mathrm{HCl} 2 \mathrm{M}$, Nacl dan ditambahkan pereaksi dragendrof. Alkaloid bersifat (bakteriosidal) berperan untuk mengganggu komponen penyusun peptidoglikan pada sel bakteri sehingga lapisan dinding sel tidak terbentuk secara utuh dan menyebabkan kematian sel tersebut (Purwaningsih, 2014).

Senyawa saponin dari uji fitokimia pada ekstrak menggunakan pelarut ethanol menunjukkan hasil positif dengan nilai $(++)$, sedangkan ekstrak menggunakan pelarut aquades menunjukkan hasil positif dengan nilai (+). Hasil uji saponin ditunjukkan dengan timbulnya gelembung atau busa pada ekstrak yang dikocok dengan penambahan aquades. Nikham (2012) menyatakan senyawa saponin bersifat (bakteriolitik) berperan sebagai antibakteri dengan meningkatkan permeabilitis membran bakteri sehingga terjadi hemolisis, atau pecahnya dinding sel bakteri kemudian mengeluarkan komponen sel mikroba (protein, asam nukleat, nukleotida dan lain-lain), membuat zat antibakteri akan masuk kedalam sel dengan mudah dan akan mengganggu metabolisme hingga akhirnya terjadi kematian bakteri. Saponin merupakan senyawa aktif berbentuk busa yang stabil bila ditambahkan asam klorida 1\% Arabski (2009). 
Bakteri Streptococcus agalactiae termasuk bakteri gram positif dengan lapisan dinding yang tipis, memiliki lipid yang rendah serta memiliki kandungan asam teikoat yang rendah yaitu $10 \%$. Asam teikoat merupakan zat yang membantu menghindari bakteri dari gangguan aktifitas hidup. Keadaan dinding sel yang tipis menyebabkan bakteri gram positif lebih mudah terhambat oleh antibakteri. Mekanisme penghambatan bakteri dilakukan dengan cara merusak dinding sel, yang dilakukan oleh senyawa alkaloid dan flavonoid, kemudian saponin akan menganggu, merusak fungsi membrane sel dan terjadai denaturasi protein dan asam nukleat, sehingga kerja enzim tergangu dan menyebabkan metabolism sel terganggu. Tanin akan gangguan DNA, RNA dan protein yang menyebabkan gangguan proses kehidupan sel (Mulyati, 2009). Ekstrak buah mahkota dewa memberikan nilai zona hambat yang tinggi karena mampu menyaring senyawa alkaloid, flavonoid, saponin dan tanin lebih banyak, sehingga mampu menyerang target utama dari dinding sel bakteri lebih optimal.

\section{KESIMPULAN}

Kesimpulan dari penelitian ini :

1. Ekstrak mahkota dewa menggunakan pelarut ethanol memiliki aktifitas antimikrobial terhadap Streptococcus agalactiae lebih tinggi dibandingkan dengan pelarut aquades. Zona hambat antimikrobial mahkota dewa dengan pelarut ethanol dan aquades berturutturut adalah $63,40 \mathrm{~mm}$ dan 27,40 $\mathrm{mm}$.

2. Kosentrasi ekstrak mahkota dewa yang paling optimal sebagai antimikrobial terhadap Streptococcus agalactiae adalah ekstrak mahkota dewa menggunakan pelarut ethanol dengan kosentrasi $50 \%$

\section{UCAPAN TERIMA KASIH}

Penulis mengucapkan terimakasih kepada :

1. DIKTI yang telah memberikan bantuan dana penelitian

2. Segenap keluarga yang memberikan dukungan serta do'a

3. Dosen pembimbing yang telah memberikan kritik dan saran

\section{DAFTAR PUSTAKA}

Arabski, Wąsik, Dworecki and Kaca. 2009. Laser Interferometric and Cultivation Methods for Measurement of Colistin/ Ampicilin and Saponin Interactions with Smooth and Rough of Proteus Mirabilis Lipopolysaccharides and Cells. Journal Microbiology of Methods. 77 (1):179-183.

Greenwood. 1995. Antibiotics, Susceptibility (Sensitivity) Test Antimicrobial And Chemoterapy. Mc. Graw Hill Company : USA.

Gunawan, I.W.G., Bawa, Sutrisnayanti. 2008. Isolasi dan Identifikasi Senyawa Terpenoid yang Aktif Antibakteri pada Herbal Meniran (Phylanthus niruri Linn.). Jurnal Kimia. 2 (1) : 31-39

Hudaya, T., A. Sabianto, And S. Prasetyo S. 2015. Tannin Removal By Hot Water As The PretreatmentOf The Multi Stages Extraction Of Phaleria Macrocarpa Bioactive Compounds. Prosiding Seminar Nasional Teknik Kimia "Kejuangan": 68 (1): 16934393.

Kristianti, A. N. 2008. Buku Ajar Fitokimia. Airlangga University Press. Surabaya

Lisdawati, V., S. Wiryowidagdo, L. Broto, S., Ardon. 2006. Brine Shrimp Lethality Test (Bsit) Dari Berbagai Fraksi Ekstrak Daging Buah Dan Kulit Biji Mahkota Dewa (Phaleria Macrocarpa L.). Bul. Penel. Kesehatan, 34 (3):111-1 18

Mulyati, E., 2009. Uji Aktivitas Antibakteri Ekstrak Etil Asetat Daun Ceremai (Phyllanthus acidus (L.) Skeels) Terhadap Staphylococcus aureus Dan Escherichia coli Dan Bioautografinya. Skripsi. Fakultas Farmasi Universitas Muhammadiyah. Surakarta. 
Nikham dan T. E. Basjir. 2012. Uji Bahan Baku Antibakteri Dari Buah mahkota dewa (Phaleria Macrocarpa (Scheff) Boerl.) Hasil Iradiasi Gamma Dan Antibiotik Terhadap Bakteri Patogen. Prosiding Pertemuan Ilmiah Ilmu Pengetahuan Dan Teknologi Bahan. 24 (6): 1411-2213.

Purwaningsih, R. T., P. Surjowardojo dan T. E. Susilorini. 2014. Efektivitas Ekstrak Daun Kersen (Muntingia calabura L.) Dengan Pelarut Ether Dan Methanol Sebagai Antibakteri Terhadap Streptococcus agalactiae Penyebab Mastitis Subklinis Pada Sapi Perah. Universitas Brawijaya. Malang

Rumondor, M. J., F. Bian, dan Febby E.F. Kandou. 2015. Daya Hambat Ekstrak Ethanol Schismatoglottis sp. Terhadap Bakteri Staphylococcus aureus dan Escherichia coli. JurnalIlmiah Sains. 15 (2) : 145-149

Salasa. 2012. Aktifitas Ekstrak Buah mahkota dewa (Phaleria macrocarpa [Scheff.] Boerl)

TerhadapPertumbuhan

Streptococcus mutans Dan Staphylococcus aureus Penyebab Karies Gigi. Tesis Program Pascasarjana Universitas Hasanuddin. Makassar.

Sani, R., F. C., Nisa, R. D.Andriani, dan J. M. Maligan. 2014. Analisis Rendemen Dan Skrining Fitokimia Ekstrak Ethanol Mikroalga Laut Tetraselmis chuii. Jurnal Pangan dan Agroindustri. Vol. 2 No. 2: 121-126

Sholikatin, E., Sarwiyono, P. Surjowardojo. 2014. Ekstrak Ethanol Daun Kersen (Muntingia calabura L.) Sebagai Antimikroba Terhadap Bakteri Streptococcus agalactiae Pada Sapi Perah Di Daerah Ngantang Malang. Skripsi Fakultas Peternakan Universitas Brawijaya. Malang
Sibuea, F., 2015. Ekstraksi Tanin Dari Kluwak (Pangium edule R.) Menggunakaan Pelarut Ethanol Dan Aquades Dan Aplikasinya Sebagai Pewarna Makanan. Tugas akhir Program Studi Teknik Kimia Fakultas Teknik Universitas Negeri. Semarang.

Tristyanto, N. 2011. Daya Anti Bakteri Ekstrak Buah mahkota dewa Terhadap Bakteri Staphylococcus Aureus. Analis Kesehatan Akademi Analis Kesehatan Malang. Malang

Widyastuti, N., T. Widiyani, dan S. Listyawati. 2006. Efek Teratogenik Ekstrak Buah MahkotaDewa (Phaleria macrocarpa (Scheff.) Boerl.) Pada Tikus Putih (Rattus Norvegicus L.) Galur Winstar. Bioteknologi, 3 (2): 56-62.

Zahro, L., dan R. Agustini. 2013. Uji Efektivitas Antibakteri Ekstrak Kasar Saponin Jamur Tiram Putih (Pleurotus ostreatus) terhadap Staphylococcus aureus dan Escherichia coli. UNESA Journal of Chemistry, 2 (3): 24-30

Zakaria Z.A., Fatimah, Mat, Zaiton, Henie, Sulaiman, Somchit, Thenamutha and Kasthuri. 2006. The In vitro Antibacterial Activity of Muntingia calabura Extract. International Journal of Pharm acology, 2 (4) : 439-442. 